\title{
Arsenic and Lead Uptake by Vegetable Crops Grown on Historically Contaminated Orchard Soils
}

\author{
M. B. McBride \\ Department of Crop and Soil Sciences, Cornell University, Ithaca, NY 14850, USA \\ Correspondence should be addressed to M. B. McBride; mbm7@cornell.edu
}

Received 11 July 2013; Accepted 29 August 2013

Academic Editor: Balwant Singh

Copyright (C) 2013 M. B. McBride. This is an open access article distributed under the Creative Commons Attribution License, which permits unrestricted use, distribution, and reproduction in any medium, provided the original work is properly cited.

\begin{abstract}
Transfer of $\mathrm{Pb}$ and As into vegetables grown on orchard soils historically contaminated by $\mathrm{Pb}$ arsenate pesticides was measured in the greenhouse. Lettuce, carrots, green beans, and tomatoes were grown on soils containing a range of total $\mathrm{Pb}(16.5-915 \mathrm{mg} / \mathrm{kg})$ and As $(6.9-211 \mathrm{mg} / \mathrm{kg})$ concentrations. The vegetables were acid-digested and analyzed for total $\mathrm{Pb}$ and As using ICP-mass spectrometry. Vegetable contamination was dependent on soil total $\mathrm{Pb}$ and As concentrations, $\mathrm{pH}$, and vegetable species. Arsenic concentrations were the highest in lettuce and green beans, lower in carrots, and much lower in tomato fruit. Transfer of $\mathrm{Pb}$ into lettuce and beans was generally lower than that of $\mathrm{As}$, and $\mathrm{Pb}$ and As were strongly excluded from tomato fruit. Soil metal concentrations as high as $400 \mathrm{mg} / \mathrm{kg} \mathrm{Pb}$ and $100 \mathrm{mg} / \mathrm{kg}$ As produced vegetables with concentrations of $\mathrm{Pb}$ and As below the limits of international health standards.
\end{abstract}

\section{Introduction}

Arsenic (As) and lead $(\mathrm{Pb})$ have been used historically in pesticides (e.g., calcium arsenate, lead arsenate, and copper arsenate) applied to orchard crops such as apples and peaches, as well as to some other crops such as potatoes. Because $\mathrm{Pb}$ is quite immobile, and As is only very slowly leached through soils $[1,2]$, the cumulative contamination of orchard soils by lead and arsenate beginning in the late 1800s persists today [3]. As old orchard lands are converted from agricultural to residential uses, the potential hazard to human health may be increased from certain exposure pathways arising from gardening and direct contact with soil. The scale of this problem is largely based on estimates that millions of acres across North America have been contaminated by arsenic and lead pesticides. Virginia may have 100,000-300,000 acres of old orchard land [3], and other states with large acreages of impacted orchard land include Washington (188,000 acres), Wisconsin (50,000 acres) and New Jersey (up to 5\% of the total agricultural acreage) [2]. The total area of historical soil contamination in New York state is uncertain, but apple production has occupied about 40-50,000 acres in recent decades, with a general long-term decline in orchard acreage and a simultaneous increase in yield. It seems likely, then, that the present apple crop acreage underestimates the total land area that may have been contaminated by $\mathrm{As}$ and $\mathrm{Pb}$ at some time in the past.

The potential transfer of soil $\mathrm{Pb}$ and As into vegetable crops is a concern when garden soils are contaminated by these toxic metals. With growing concern about dietary exposure to these two toxic elements, a number of guidelines have been developed for recommended limits of $\mathrm{Pb}$ and $\mathrm{As}$ in vegetables and other food crops. For example, the European Union has set standards for $\mathrm{Pb}$ at $0.1 \mathrm{mg} \mathrm{kg}^{-1}$ (fresh weight or f.w.) for fruits and roots and $0.3 \mathrm{mg} \mathrm{kg}^{-1}$ (f.w.) for leafy greens. Few official standards exist at present specifically for As in vegetables, although several government agencies have recommended As limits close to $0.1 \mathrm{mg} \mathrm{kg}^{-1}$ (f.w.). No standards for $\mathrm{Pb}$ and As in vegetables, fruits, or other staple food crops exist in the United States as yet.

A number of older published studies have measured As and $\mathrm{Pb}$ transfer into vegetables grown on historically lead arsenate-contaminated orchard soils. Generally, the degree of contamination of the edible portion of the crops was relatively small, especially for fruits [4-7]. Creger and Peryea [7] measured As in apple and apricot fruits grown on lead arsenate-contaminated soils. Although they found $\mathrm{Pb}$ in 
the fruit to be below the analytical detection limits, As concentration reached as high as $70 \mu \mathrm{g} \mathrm{kg}^{-1}$ (f.w. basis) in the fruit and was correlated with the $\mathrm{HCl}$-extractable soil As (which ranged from 0 to $100 \mathrm{mg} \mathrm{kg}^{-1}$ in these soils). Thus, the degree of fruit contamination depended on strong acidextractable soil As concentration, which is correlated with total soil As. However, leafy and root crops have shown higher levels of $\mathrm{As}$ and $\mathrm{Pb}$ contamination. In particular, the relatively high water solubility of soil As measured by a number of studies of lead arsenate-contaminated orchard soils suggests that the potential for As uptake into roots and leaf tissues of some crops could be significant. In fact, As uptake is frequently high enough to cause phytotoxicity in sensitive crops $[8,9]$. McBride et al. [10] found in one greenhouse experiment that uptake of As into leafy green vegetables from severely contaminated orchard soil (containing 220 and $1300 \mathrm{mg} \mathrm{kg}^{-1}$ of total As and $\mathrm{Pb}$, resp.) was relatively high (near $10 \mathrm{mg} \mathrm{kg}^{-1}$ As, d.w. basis) and substantially greater than that of $\mathrm{Pb}$ (about $3 \mathrm{mg} \mathrm{kg}^{-1} \mathrm{~Pb}$ d.w.), consistent with the much higher water solubility of As compared to $\mathrm{Pb}$ measured in the soil. These leafy green concentrations, when converted to approximate $\mathrm{As}$ and $\mathrm{Pb}$ concentrations on a fresh weight (f.w.) basis, exceed WHO limits for As but are somewhat below EU recommendations for $\mathrm{Pb}$.

Despite the potential risk to vegetable and fruit crops grown on old orchard soils, particularly from As uptake, few recent studies of the transfer of these toxic metals from lead arsenate-contaminated soils into such crops have been published. Because of increasing awareness of the toxicity of $\mathrm{Pb}$ and $\mathrm{As}$ to humans as discussed above and because most older studies of $\mathrm{Pb}$ and As uptake from orchard soils used relatively insensitive analytical methods, the present study was undertaken to measure uptake of $\mathrm{Pb}$ and $\mathrm{As}$ from a historically lead arsenate-contaminated soil into vegetables using a highly sensitive method (ICP-MS) for $\mathrm{Pb}$ and $\mathrm{As}$ analysis.

\section{Materials and Methods}

2.1. Properties of Soil Samples. Surface soils $(0-15 \mathrm{~cm})$ were sampled in October of 2009 at locations preselected within the Cornell Orchard to represent a wide range of total $\mathrm{Pb}$ and As. These soils are labeled A1, A3, A6, H11, and G6. A control soil, collected at the same time from a nearby field (Caldwell field) outside of the orchard, contained low (nearbackground) $\mathrm{Pb}$ and As concentrations. All soils are classified as Hudson series, with the same silty clay loam texture, and were selected with the expectation that they would have quite similar physicochemical properties with the exception of their total $\mathrm{Pb}$ and As concentrations. The soils were airdried, thoroughly mixed and stored in large plastic containers in preparation for the greenhouse experiment.

Soil subsamples were taken in triplicate from the containers and further ground using a mortar and pestle prior to analysis for total $\mathrm{Pb}$ and $\mathrm{As}$. Measurement of $\mathrm{pH}$ was done in deionized water ( $1: 1$ soil/water ratio) by glass electrode, and organic matter concentration by the Walkley-Black dichromate oxidation method [11]. The effective $\mathrm{CEC}\left(\mathrm{CEC}_{\mathrm{e}}\right)$ of the soils was determined by measuring exchangeable base cation concentration $(\mathrm{Ca}+\mathrm{Mg}+\mathrm{K})$, using the modified Morgan extraction method (1 M ammonium acetate at $\mathrm{pH} 4.8)$ to dissolve the cations [12] and flame atomic absorption to measure them in the filtered extracts. Free Fe and Mn oxide concentrations in the orchard soils were measured earlier [13] and were found to be quite low at $1.1 \mathrm{~g} \mathrm{~kg}^{-1} \mathrm{Fe}$ and $0.12 \mathrm{~g} \mathrm{~kg}^{-1} \mathrm{Mn}$. Soils were digested using EPA method 3051, and the digests were analyzed for $\mathrm{Pb}$ and As by ICP-OES. The measured properties of these soils are given in Table 1, with the soils being ranked in the order of increasing total $\mathrm{Pb}$ and As.

In order to determine the initial solubility of $\mathrm{Pb}$ and $\mathrm{As}$ in the soils listed in Table 1 prior to their use in the greenhouse experiment, about $250 \mathrm{~g}$ samples of soil (in duplicate) were taken from the storage containers and placed in Buchner funnel cups fitted with Whatman \#42 filter papers, then brought to field capacity with deionized water. After 24 hours of equilibration, pore water was collected from the soils by vacuum extraction, then put through $0.2 \mu \mathrm{m}$ membrane filters, stabilized with $0.1 \mathrm{~mL}$ concentrated ultrapure $\mathrm{HNO}_{3}$, and analyzed for $\mathrm{Pb}$ and As by ICP-MS. The average measured soil $\mathrm{Pb}$ and As solubilities are listed in the last two columns of Table 1.

2.2. Greenhouse Pot Experiment. Labeled plastic pots with bottom drainage holes were filled with $5.5 \mathrm{~kg}$ (dry wt.) of the 6 soils, with 4 replicate pots for each soil. The soils were brought to a field-moist state with tap water, and lettuce seeds ("Simpson Elite") were planted in the pots placed on a table in the greenhouse. Supplemental overhead lighting (12 hours/day) was provided, and temperature was maintained near $21^{\circ} \mathrm{C}$ (day) and $10^{\circ} \mathrm{C}$ (night). After seedlings were established, they were thinned to about 6/pot, a plant density that resulted in a full canopy at harvest. As some evidence of $\mathrm{N}$ deficiency was noted after the first two weeks of lettuce growth, a small quantity of a slow-release NPK fertilizer was applied to the soil surface of each pot, equivalent to approximately 100,15 and $50 \mathrm{~kg} \mathrm{ha}^{-1}$ of $\mathrm{N}, \mathrm{P}$, and $\mathrm{K}$, respectively. Pots were watered when the soil was visibly dry, with care taken to minimize leaching of water through the pots.

The lettuce was harvested 40 days after planting by cutting the tops about $1 \mathrm{~cm}$ above the soil surface. The lettuce was carefully washed in tap water, excess water was removed, and the lettuce was dried in paper bags in the oven at $60-$ $70^{\circ} \mathrm{C}$. The dried lettuce tissues were then ground using a coffee grinder, placed in labeled Whirl-Pak bags, and aciddigested. The digests were analyzed for $\mathrm{Pb}$ and As by ICPMS. After the lettuce harvest, the same pots were planted with carrots after a 1-month "fallow" period in early 2010 (cv. "Royal Chantenay"). After 10 weeks, the carrots were thinned to 8 plants/pot. Carrot roots were harvested after 3 months, washed, and scrubbed thoroughly to remove all soil particles. The carrot roots were then divided into two sample groups, one peeled and one not peeled. All the carrot roots were then thin-sliced, dried in paper bags in the oven at $60-70^{\circ} \mathrm{C}$, ground using a coffee grinder, and stored in small 
TABLE 1: Important properties and total and water-soluble $\mathrm{Pb}$ and $\mathrm{As}$ of the orchard soils. Standard deviations of mean values based on duplicate measurements are reported for $\mathrm{CEC}_{\mathrm{e}}$ and total and soluble $\mathrm{Pb}$ and $\mathrm{As}$.

\begin{tabular}{|c|c|c|c|c|c|c|c|}
\hline Soil & $\mathrm{pH}$ & $\mathrm{CEC}_{\mathrm{e}}(\mathrm{mmoles} / \mathrm{kg})$ & OM (\%) & Total Pb (mg/kg) & Total As $(\mathrm{mg} / \mathrm{kg})$ & Soluble $\mathrm{Pb}(\mu \mathrm{g} / \mathrm{L})$ & Soluble As $(\mu \mathrm{g} / \mathrm{L})$ \\
\hline Control & 5.9 & $101 \pm 2$ & 2.50 & $16.5 \pm 0.8$ & $6.9 \pm 0.5$ & $2.5 \pm 0.7$ & $6.5 \pm 0.7$ \\
\hline $\mathrm{A} 1$ & 5.8 & $133 \pm 35$ & 5.30 & $123 \pm 16$ & $35.8 \pm 2.4$ & $9.5 \pm 0.7$ & $19 \pm 1.4$ \\
\hline A3 & 6.2 & $135 \pm 9$ & 4.75 & $244 \pm 14$ & $67.8 \pm 3.8$ & $57.5 \pm 3.5$ & $83.5 \pm 3.5$ \\
\hline H11 & 4.9 & $48 \pm 6$ & 5.00 & $289 \pm 38$ & $70.6 \pm 1.9$ & $72 \pm 17$ & $35 \pm 2.8$ \\
\hline A6 & 6.5 & $159 \pm 11$ & 5.13 & $400 \pm 39$ & $91.3 \pm 7.9$ & $20 \pm 19.8$ & $124 \pm 7$ \\
\hline G6 & 6.2 & $174 \pm 3$ & 7.40 & $915 \pm 149$ & $211 \pm 49$ & $153 \pm 69$ & $745 \pm 80$ \\
\hline
\end{tabular}

labeled whirl-pak bags. Samples were digested and analyzed for $\mathrm{Pb}$ and $\mathrm{As}$ as described above for lettuce. All $\mathrm{Pb}$ and $\mathrm{As}$ concentrations in vegetable samples are reported as $\mathrm{mg} \mathrm{kg}^{-1}$ on a dry weight (d.w.) basis.

The cropping sequence was continued with 1-year fallow periods for the final two crops because experience had shown the crops to grow poorly in the greenhouse during the summer months when temperature control was inadequate. Thus, bush beans (cv. "Roma II") were planted in April 2011 and thinned to 3 plants/pot. The green bean pods were harvested at the edible stage, 54 days after planting, washed, dried, ground, and analyzed for $\mathrm{Pb}$ and $\mathrm{As}$ as described above for the other crops.

The final crop, tomato (cv. "Sub-Arctic Plenty"), was planted using prestarted seedlings (1 per pot) in April 2012. A small amount of slow-release NPK fertilizer, equivalent to about 300,45 , and $160 \mathrm{~kg} \mathrm{ha}^{-1}$ of $\mathrm{N}, \mathrm{P}$ and $\mathrm{K}$, respectively, was applied to the soil surface of each pot. Ripe tomatoes were harvested from each of the pots 78 days after planting, washed, cut into pieces, dried in glass jars at $60-70^{\circ} \mathrm{C}$, ground, and analyzed for $\mathrm{Pb}$ and $\mathrm{As}$ as described above for the other crops.

The lowest crop yields were generally measured for the control and H11 soil, attributable to the low $\mathrm{pH}$ of H11 and poor structure (low organic matter) of the control (see Table 1), while the highest yields were found for A3 and G6 (data not shown). Because there was no apparent relationship between plant growth in the different soils and soil total $\mathrm{Pb}$ or As, attributable to the fact that soil variables other than metal concentration (e.g., soil organic matter concentration) most strongly affected plant growth, it was not possible to determine whether arsenic was phytotoxic to any of the crops.

All plant tissue $\mathrm{As}$ and $\mathrm{Pb}$ concentrations are reported in the results section as $\mathrm{mg} \mathrm{kg}^{-1}$ on a d.w. basis, although for purposes of converting these to approximate f.w. concentrations for comparison with international food guidelines, measured water concentration of $94.9 \%$ (lettuce), $87 \%$ (carrots), $89 \%$ (green beans), and 94\% (tomato) were used.

Data analysis included linear regression of crop As and $\mathrm{Pb}$ concentrations against soil total $\mathrm{As}$ and $\mathrm{Pb}$, with the significance of regression $r$-values at the 5\% level determined by the standard $t$-test. ANOVA was conducted on the data using the StatView software (SAS Institute, Cary, NC, USA) in order to determine the significance of the soil and crop type as factors in determining the concentrations of $\mathrm{As}$ and $\mathrm{Pb}$ in the edible crop tissues.

\section{Results and Discussion}

3.1. Soil Properties. The soils selected for the greenhouse study had a range of total $\mathrm{Pb}$ of 16.5 to $915 \mathrm{mg} / \mathrm{kg}$ and total As of 6.9 to $211 \mathrm{mg} \mathrm{kg}^{-1}$ (Table 1), with the soil concentrations of the two elements being very closely correlated. Soluble $\mathrm{Pb}$ and As generally increased with increasing total soil $\mathrm{Pb}$ and As, respectively. However, soil A6 had lower soluble $\mathrm{Pb}$ than expected by comparison with its total $\mathrm{Pb}$, which can probably be explained by the fact that $\mathrm{A} 6$ had the highest $\mathrm{pH}$ (6.5) of the studied soils. Soil H11 had lower As solubility relative to its total As concentration compared to the other soils, possibly a consequence of the low $\mathrm{pH}$ (4.9) of this soil, as acid conditions are expected to favor adsorption of anions such as arsenate and phosphate on soils based on their adsorption behavior on model iron oxides [14]. However, comparisons of soils with different properties have shown soil $\mathrm{pH}$ to be much less important than soil reactive Fe oxides in controlling arsenate adsorption $[15,16]$. The low $\mathrm{pH}$ and exchangeable base cation concentration of soil H1l was unanticipated; it is suspected that the soil in the field location where H11 was sampled had been intentionally acidified in order to establish blueberry plants some years earlier.

Because soil H11 was much more acidic than the other soils used for this greenhouse study, poor growth and much higher $\mathrm{Pb}$ uptake were observed for most crops grown on this soil. As a result, it was decided to exclude the data for this soil from the overall comparison of $\mathrm{Pb}$ and $\mathrm{As}$ uptake over the range of soil $\mathrm{Pb}$ and As concentrations represented by the other soils. Fortunately, soil $\mathrm{A} 3 \mathrm{had} \mathrm{Pb}$ and As concentrations similar to those of H1l, so that a comparison of $\mathrm{Pb}$ and $\mathrm{As}$ uptake into the crops between these two soils provided a useful test of the effect of soil $\mathrm{pH}$ on phytoavailability of these metals.

Because the soils were used in a sequential cropping experiment in the greenhouse, it is very possible that solubilities of $\mathrm{Pb}$ and $\mathrm{As}$ and $\mathrm{pH}$ in the soils could have fluctuated from their initially measured values due to rhizosphere effects of the different crops and microbial activity. As the scope of this study did not include detailed monitoring of $\mathrm{Pb}$ and As concentrations in soil solution, only the total $\mathrm{Pb}$ and $\mathrm{As}$ concentrations in the soil were tested as predictors of plant uptake, recognizing that these are easier to measure and are more stable over time than dissolved concentrations. The soil $\mathrm{pH}$ values measured at the end of the cropping sequence (not shown) tended to be several tenths of a $\mathrm{pH}$ unit higher than 
the initial $\mathrm{pH}$ values given in Table 1, but soil H11 remained substantially more acidic than the other soils.

3.2. Lettuce Crop. The concentrations of both $\mathrm{Pb}$ and $\mathrm{As}$ in the harvested lettuce increased with increasing soil concentrations of these two contaminants (Figure 1). The plant uptake coefficients (UC), defined as the ratio of crop metal concentration $\left(\mathrm{mg} \mathrm{kg}^{-1}\right.$, d.w.) to the soil total metal concentration $\left(\mathrm{mg} \mathrm{kg}^{-1}\right)$, were much higher for As than for $\mathrm{Pb}$, with the highest UCs for both $\mathrm{As}$ and $\mathrm{Pb}$ being measured at the highest soil concentrations. Arsenic is readily taken up by leafy green crops, whereas $\mathrm{Pb}$ generally has a low tendency for uptake into above-ground tissues because of its very low solubility in soils that are not strongly acidic $[10,17]$. However, the UC for As in leafy vegetables is strongly dependent on plant species [17]. Our (unpublished) field studies of As uptake by vegetables grown on orchard soils show lettuce to be intermediate in potential for As uptake, higher than spinach and collards but lower than arugula (which averaged $12-13 \mathrm{mg} \mathrm{kg}^{-1}$ As when grown on soils with $60-120 \mathrm{mg} \mathrm{kg}^{-1}$ total As).

3.3. Carrot Crop. The concentrations of both $\mathrm{Pb}$ and $\mathrm{As}$ increased in the harvested carrot roots with increasing soil concentrations of these two contaminants (Figures 2 and 3 ), with carrot As showing an increasing uptake coefficient as soil As increased. A lower carrot $\mathrm{Pb}$ concentration than expected at the $400 \mathrm{mg} \mathrm{kg}^{-1}$ soil $\mathrm{Pb}$ concentration, based on the general trend in the data of Figure 3, is possibly the result of the somewhat higher soil $\mathrm{pH}$ in the $\mathrm{A} 6$ soil containing $400 \mathrm{mg} \mathrm{kg}^{-1} \mathrm{~Pb}$.

Peeling the carrots before analysis had a small effect in increasing the root $\mathrm{Pb}$ concentrations, which ANOVA showed to be significant at the $5 \%$ level $(P=0.032)$. Such an effect suggests that the outer layers of the carrot root were lower in $\mathrm{Pb}$ than the bulk of the root. Peeling appeared to have a marked effect in reducing the root As concentrations, particularly in the most As-contaminated carrots (Figure 2), although ANOVA revealed that this effect did not quite reach significance at the $5 \%$ level $(P=0.063)$. A similar effect of peeling, producing opposite effects on $\mathrm{As}$ and $\mathrm{Pb}$ concentrations in carrots, was noted by Codling et al. [18].

Numerous studies indicate that $\mathrm{Pb}$ uptake from contaminated soils into root crops such as carrots is greater than that into vegetable fruits and sometimes comparable to or higher than transfer into leafy greens [19-22]. In this study, the carrot root concentrations were higher than those in lettuce but exceeded $1 \mathrm{mg} \mathrm{kg}^{-1}$ (dry wt. basis) only at the highest soil $\mathrm{Pb}$ concentration (G6, with total $\mathrm{Pb}$ exceeding $900 \mathrm{mg} \mathrm{kg}^{-1}$ ). The As concentrations in the peeled and unpeeled carrots (Figure 2), in contrast, were lower than those in lettuce (Figure 1).

3.4. Bean Crop. The trend of increasing As in the harvested bean crop with increasing soil As is evident in Figure 4; the relative increase in crop As was sufficiently large that the As concentrations are best displayed on a logarithmic scale. However, there was no significant increase of $\mathrm{Pb}$

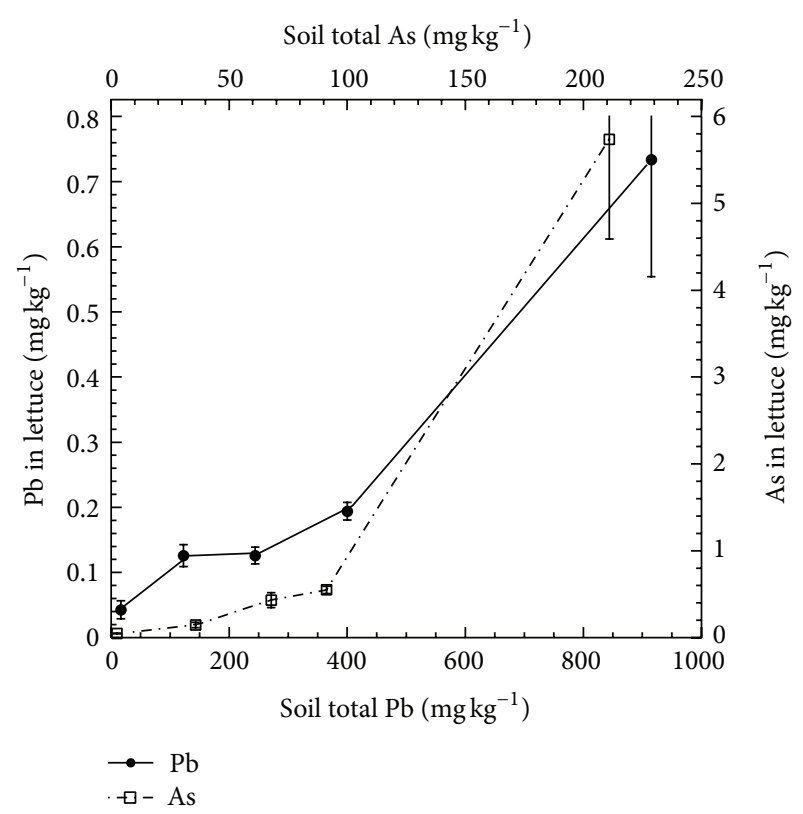

FIgURE 1: $\mathrm{Pb}$ and As concentrations ( $\mathrm{mg} \mathrm{kg}^{-1}$ d.w.) in lettuce grown on orchard soils containing a range of $\mathrm{Pb}$ and As. Error bars in this figure and subsequent figures depict plus and minus one standard deviation unit.

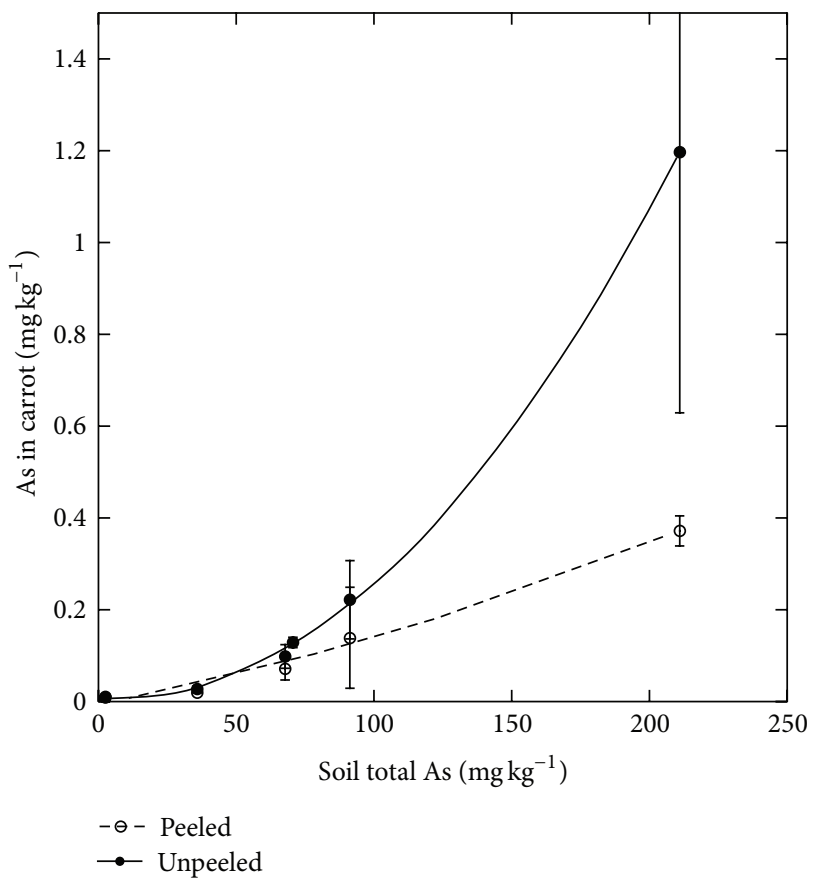

FIgURE 2: As concentrations ( $\mathrm{mg} \mathrm{kg}^{-1}$ d.w.) in peeled and unpeeled carrot roots grown on orchard soils containing a range of As concentrations.

concentration in the edible bean pods with increasing soil $\mathrm{Pb}$ even at the highest soil $\mathrm{Pb}$ concentration. These results are consistent with the known tendency of plants to exclude $\mathrm{Pb}$ from the fruiting part of the plant [19-21]. Arsenic is not only more soluble and bioavailable than $\mathrm{Pb}$ in soils but also has a greater ability to translocate from roots to shoots in 


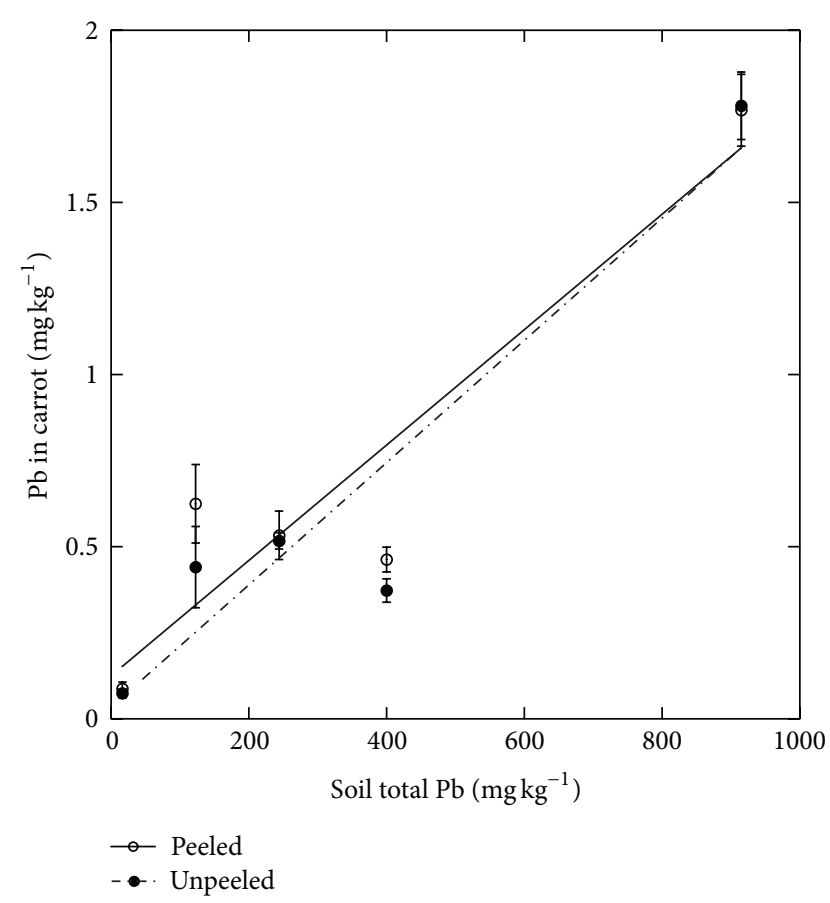

FIGURE 3: $\mathrm{Pb}$ concentrations ( $\mathrm{mg} \mathrm{kg}^{-1}$ d.w.) in peeled and unpeeled carrot roots grown on orchard soils containing a range of $\mathrm{Pb}$ concentrations.

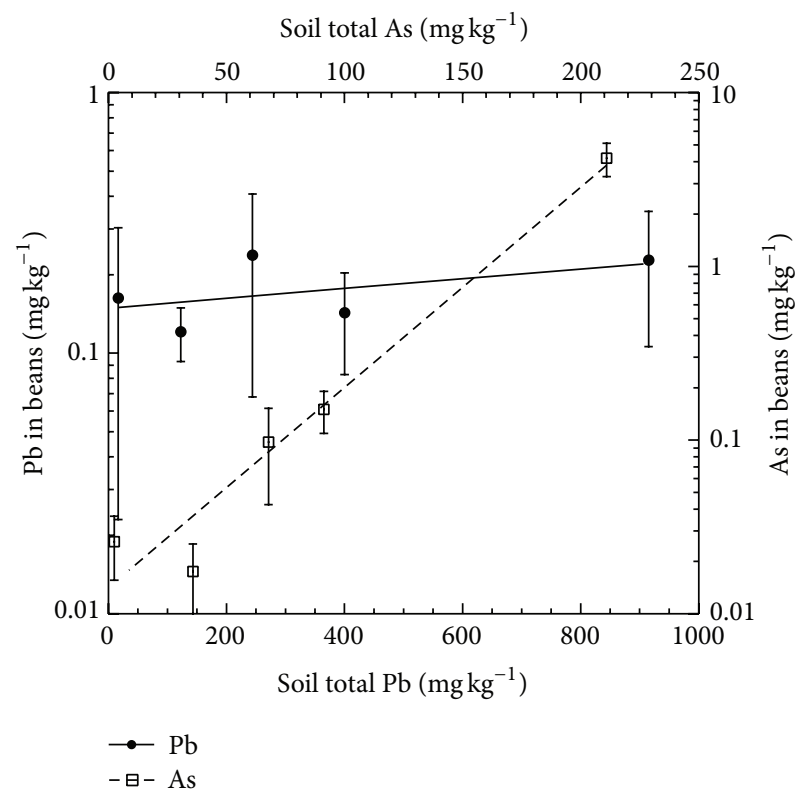

Figure 4: $\mathrm{Pb}$ and As concentrations $\left(\mathrm{mg} \mathrm{kg}^{-1}\right.$ d.w.) in green bean pods grown on orchard soils containing a range of $\mathrm{Pb}$ and $\mathrm{As}$ concentrations.

particular species such as members of the brassica family [23]. Thus, the As concentration in the edible bean pods averaged $4.2 \mathrm{mg} \mathrm{kg}^{-1}$ (d.w.) at the highest soil As concentration (G6, with total As exceeding $200 \mathrm{mg} \mathrm{kg}^{-1}$ ), much higher than the $\mathrm{Pb}$ concentration in beans grown on the same soil.

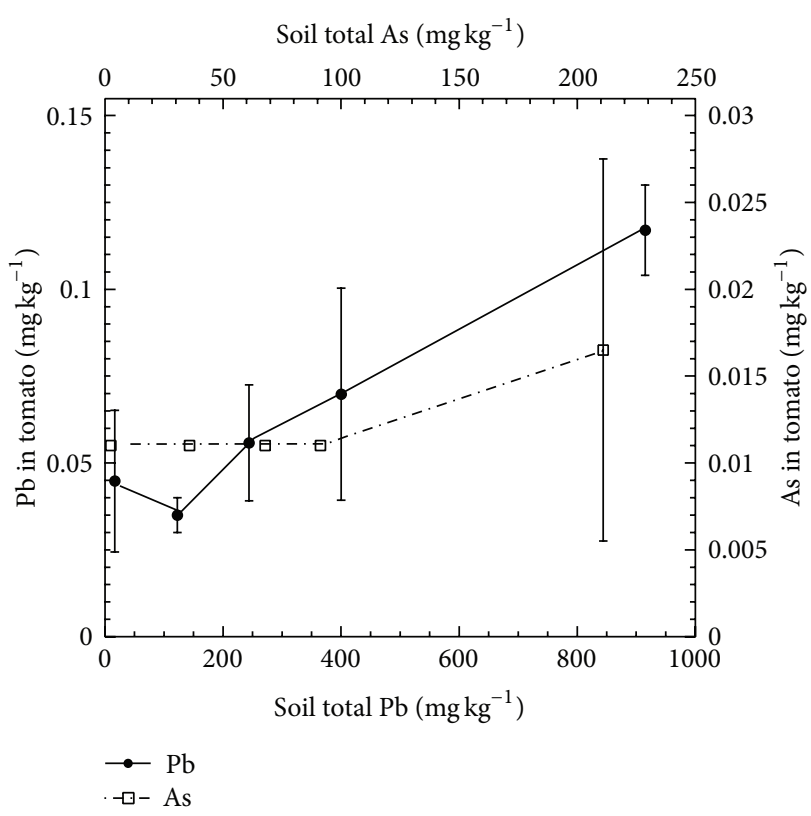

Figure 5: $\mathrm{Pb}$ and As concentrations ( $\mathrm{mg} \mathrm{kg}^{-1}$ d.w.) in tomato fruit grown on orchard soils containing a range of $\mathrm{Pb}$ and $\mathrm{As}$.

3.5. Tomato Crop. As shown by Figure 5 , transfer of soil $\mathrm{Pb}$ and As into the tomato fruit was very limited, with only a small tendency for increasing $\mathrm{Pb}$ and $\mathrm{As}$ in soil to result in higher concentrations of these elements in the fruit. Only the fruit grown on soil with the highest $\mathrm{Pb}$ concentration contained a statistically higher concentration of $\mathrm{Pb}$ than the fruit grown on the control soil. In the case of As, none of the tomato fruit grown on the As-contaminated soils contained significantly higher As concentrations than the control fruit. These results are consistent with the general observation that the barrier to translocation of $\mathrm{Pb}$ within the plant protects fruit crops from significant $\mathrm{Pb}$ contamination [19]. The results also indicate that the well-known physiological barrier to As transfer from the vegetative part of the plant into seeds and fruits [24] is more pronounced in tomato than bean.

\section{6. $\mathrm{Pb}$ and As Uptake by All Crops}

3.6.1. Pb and As Plant Uptake Factors. ANOVA revealed that, for $\mathrm{As}$ and $\mathrm{Pb}$, both the soil factor and crop type were highly significant $(P<0.0001)$ in determining the concentration of these elements in the edible crop. Each crop contained significantly different concentrations of both $\mathrm{As}$ and $\mathrm{Pb}$ when grown on the same soil, and therefore crops had different UCs. The effect of the different soils on $\mathrm{Pb}$ and As uptake is largely attributable to the very different concentrations of $\mathrm{Pb}$ and As in the soils selected for the study (with the exception of the strong impact of low $\mathrm{pH}$ in one soil (H11), which was excluded from the ANOVA).

Table 2 summarizes slopes and $r$-values of linear regressions that relate plant tissue $\mathrm{Pb}$ and As concentrations to total and water-soluble $\mathrm{Pb}$ and $\mathrm{As}$ concentrations, respectively. Whereas all linear relationships between the vegetable crop 
TABLE 2: Linear regression slopes and $r$-values (in parentheses) for correlations between vegetable $\mathrm{Pb}$ and As concentrations $\left(\mathrm{mg} \mathrm{kg}^{-1}\right)$ and soil soluble $\left(\mathrm{mg} \mathrm{L}^{-1}\right)$ and total $\mathrm{Pb}$ and $\mathrm{As}\left(\mathrm{mg} \mathrm{kg}^{-1}\right) . r$-values denoted with asterisks are significant at the $5 \%$ level.

\begin{tabular}{lccc}
\hline \multirow{2}{*}{ Crop } & \multirow{2}{*}{ Metal } & \multicolumn{2}{c}{ Soil parameter tested } \\
& & Soluble metal & Total metal \\
\hline \multirow{2}{*}{ Lettuce } & $\mathrm{Pb}$ & $3.08(0.805)$ & $0.000769\left(0.970^{*}\right)$ \\
& $\mathrm{As}$ & $6.53\left(0.998^{*}\right)$ & $0.0288\left(0.939^{*}\right)$ \\
Carrot (unpeeled) $)$ & $\mathrm{Pb}$ & $12.4(0.717)$ & $0.00177\left(0.943^{*}\right)$ \\
& $\mathrm{As}$ & $1.59\left(0.997^{*}\right)$ & $0.00609\left(0.955^{*}\right)$ \\
Bean (pods) & $\mathrm{Pb}$ & $1.16(0.346)$ & $7.70 \times 10^{-5}(0.521)$ \\
& $\mathrm{As}$ & $5.85\left(0.991^{*}\right)$ & $0.0213\left(0.918^{*}\right)$ \\
Tomato (fruit) & $\mathrm{Pb}$ & $0.516\left(0.851^{*}\right)$ & $8.91 \times 10^{-5}\left(0.977^{*}\right)$ \\
& $\mathrm{As}$ & $0.0073\left(0.942^{*}\right)$ & $2.80 \times 10^{-5}\left(0.908^{*}\right)$ \\
\hline
\end{tabular}

As concentrations and soil total As or soluble As concentrations were significant $(P<0.05)$, virtually none of the comparable vegetable $\mathrm{Pb}$-soil $\mathrm{Pb}$ relationships were. This means that As uptake into all crops was predicted more reliably by soil parameters (soluble or total $\mathrm{As}$ ) than $\mathrm{Pb}$ uptake (as indicated by the greater $r$-values for $\mathrm{As}$ ). Soluble $\mathrm{Pb}$ and As in the soils were only marginally better predictors of the uptake into the crops than total soil $\mathrm{Pb}$ and $\mathrm{As}$ (as indicated by somewhat higher $r$-values).

Plant uptake coefficients (UCs), quantified by the uptake slopes for the crop metal-total soil metal regressions (see the last column of Table 2), show As UCs to be higher than those of $\mathrm{Pb}$ for the edible part of all crops except tomatoes. However, when these uptake factors are recalculated based on soluble rather than total metals in the soils, UCs for As are not consistently higher than those for $\mathrm{Pb}$, an indication that low uptake of $\mathrm{Pb}$ into the crops is largely explained by very low $\mathrm{Pb}$ solubility in the soils, with the plant physiological barrier to uptake being a secondary factor.

3.6.2. Soil $p H$ Effect on $P b$ and As Uptake. Because soils $\mathrm{A} 3$ and $\mathrm{H} 11$ had similar $\mathrm{Pb}$ and As contamination levels but very different $\mathrm{pH}$ values and exchangeable base cation concentrations, it was possible to compare the uptake of $\mathrm{Pb}$ and $\mathrm{As}$ into the four vegetable crops as being affected primarily by soil $\mathrm{pH}$. The results of this comparison are shown in Figure 6 (for $\mathrm{Pb}$ ) and Figure 7 (for As). ANOVA revealed that both the soil factor (soil $\mathrm{pH}$ ) and crop type were highly significant $(P<0.0001)$ factors in determining crop $\mathrm{Pb}$ concentration, and all crops were significantly $(P<$ 0.002 ) different in $\mathrm{Pb}$ concentration. As expected based on the dependence of soil $\mathrm{Pb}$ solubility on $\mathrm{pH}$, the lettuce and carrots grown on the more strongly acid soil had much higher $\mathrm{Pb}$ concentrations. For the vegetable fruits (bean and tomato), $\mathrm{Pb}$ was also higher for crops grown on the more acid soil, but the relative effect of $\mathrm{pH}$ on the uptake into these vegetables was smaller. The order of $\mathrm{Pb}$ concentration in the edible portion of the crops grown on the acid soils was

lettuce $>$ carrot $\gg$ bean $\gg$ tomato.

This order was different for the soil at $\mathrm{pH}$ 6.2, with carrot roots being the strongest $\mathrm{Pb}$ accumulator and lettuce having markedly reduced $\mathrm{Pb}$ uptake at the higher $\mathrm{pH}$.

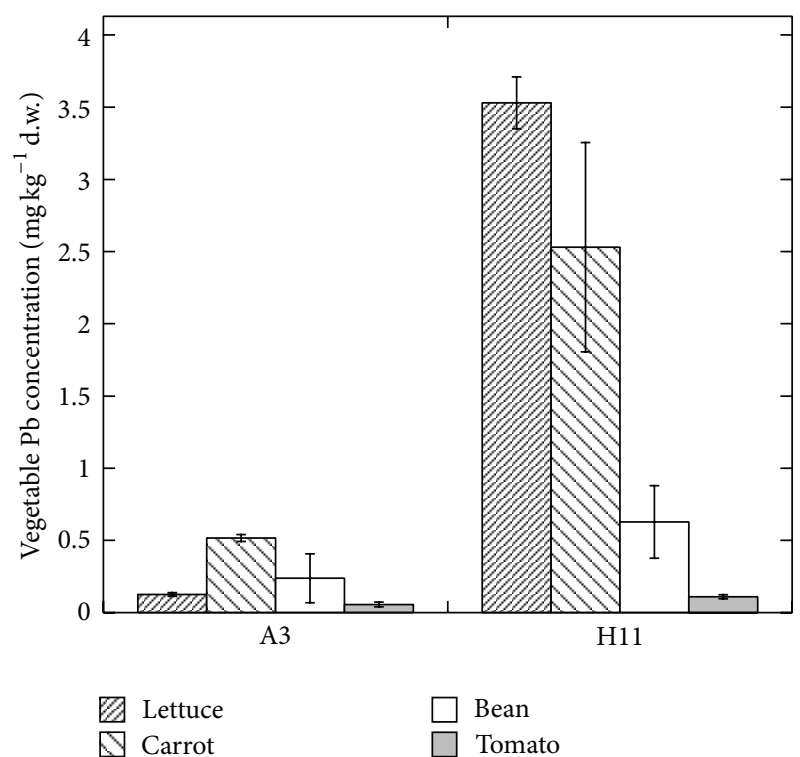

FIGURE 6: $\mathrm{Pb}$ concentrations $\left(\mathrm{mg} \mathrm{kg}^{-1}\right.$ d.w.) in lettuce, carrot, bean and tomato grown on orchard soils with similar total $\mathrm{Pb}$ but $\mathrm{pH}$ of 6.2 (A3) and 4.9 (H11).

ANOVA showed that, in contrast to the result for $\mathrm{Pb}$, the difference in $\mathrm{pH}$ of the soils $\mathrm{A} 3$ and $\mathrm{H} 11$ was not a significant factor in determining the As concentration in the crops (see Figure 7), although the crop type was still highly significant $(P<0.0001)$. It is apparent from Figure 7 that As uptake was not strongly affected by soil $\mathrm{pH}$, but the crop type strongly affected As accumulation which followed the order

$$
\text { lettuce } \gg \text { carrot } \geq \text { bean } \gg \text { tomato. }
$$

The insensitivity of As uptake by the crops to soil $\mathrm{pH}$ may reflect the fact that As adsorption in these orchard soils is weaker than that of $\mathrm{Pb}$ and may be less $\mathrm{pH}$ sensitive. Although As adsorption on variable-charge soil minerals such as Fe oxides increases at lower $\mathrm{pH}$ [14], adsorption on soils dominated by layer silicate clay mineralogy such as the orchard soils used in this study is not very $\mathrm{pH}$ dependent in the $\mathrm{pH} 4.5-7.5$ range [25]. Table 1 shows the less acid soil (A3) to have soluble As only about 2-fold higher than that of the strongly acid soil (H11), suggesting that As solubility and phytoavailability in these orchard soils are controlled to a greater degree by total soil As burden than $\mathrm{pH}$.

3.7. Implications for Human Health. In order to provide an assessment of the potential health risk to gardeners consuming vegetables grown on old orchard site soils, the measured $\mathrm{Pb}$ and $\mathrm{As}$ in the vegetables grown on the greenhouse study were compared to international standards. For $\mathrm{Pb}$, the EU standards have limits of $0.1 \mathrm{mg} \mathrm{kg}^{-1}$ (f.w.) for most vegetables, but a higher limit of $0.3 \mathrm{mg} \mathrm{kg}^{-1}$ for leafy greens. For As, a limit of $0.1 \mathrm{mg} \mathrm{kg}^{-1}$ (f.w.) has been recommended by health agencies within several countries. Using approximate water concentrations of the four vegetables included in this study, these maximum limits were converted to $\mathrm{Pb}$ and $\mathrm{As}$ concentrations on a dry weight (d.w.) basis, and the vegetable 


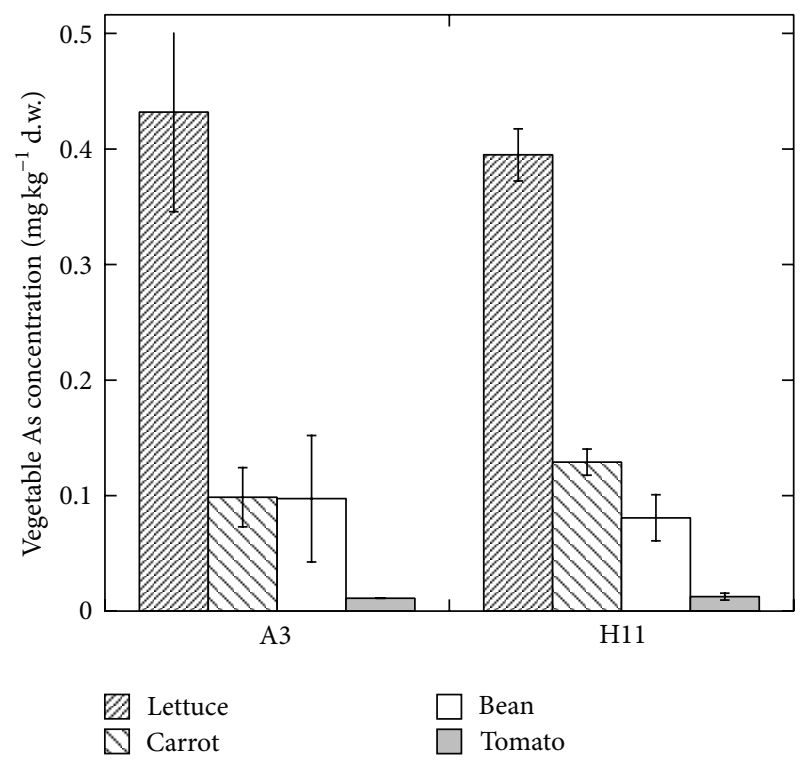

FIgURE 7: As concentrations ( $\mathrm{mg} \mathrm{kg}^{-1}$ d.w.) in lettuce, carrot, bean, and tomato grown on orchard soils with similar total As but $\mathrm{pH}$ of 6.2 (A3) and 4.9 (H11).

$\mathrm{Pb}$ and $\mathrm{As}$ concentration data presented in Figures 1-5 were compared to these limits. For lettuce, these dry weight-based recommended limits are $5.9 \mathrm{mg} \mathrm{kg}^{-1}$ for $\mathrm{Pb}$ and $2.0 \mathrm{mg} \mathrm{kg}^{-1}$ for As. For carrots, the limits are $0.8 \mathrm{mg} \mathrm{kg}^{-1}$ for both $\mathrm{Pb}$ and As. For beans and tomatoes, they are 0.9 and $1.7 \mathrm{mg} \mathrm{kg}^{-1}$, respectively, for both $\mathrm{Pb}$ and $\mathrm{As}$.

Inspection of Figures $1-5$ reveals that, for lettuce, $\mathrm{Pb}$ levels remained well below the recommended limit even at a soil total $\mathrm{Pb}$ concentration of $915 \mathrm{mg} \mathrm{kg}^{-1}$. Conversely, As exceeded its limit once soil total As was somewhat in excess of $100 \mathrm{mg} \mathrm{kg}^{-1}$. For carrots, $\mathrm{Pb}$ exceeded the limit only when grown on the soil containing the highest $\mathrm{Pb}$ level $\left(915 \mathrm{mg} \mathrm{kg}^{-1}\right)$, although it also exceeded the limit in the strongly acidic soil (H11) containing much lower $\mathrm{Pb}$ (see Figure 6). Carrot As exceeded the limit only when unpeeled and grown on the soil with highest As $\left(211 \mathrm{mg} \mathrm{kg}^{-1}\right)$. Peeled carrots had As concentrations well below the limit even at the highest soil As level tested. For bush beans, $\mathrm{Pb}$ uptake into the edible pods was very insensitive to $\mathrm{Pb}$ concentration in the soil, and $\mathrm{Pb}$ concentrations in the edible crop were well below the $\mathrm{Pb}$ limit. This result indicates a strong physiological barrier to $\mathrm{Pb}$ translocation into the reproductive tissues of the crop. Conversely, As transfer into the bean pods was strongly sensitive to soil total As and exceeded the As limit in soils with total As higher than about $100-150 \mathrm{mg} \mathrm{kg}^{-1}$. This result indicates that As has a weaker physiological barrier than $\mathrm{Pb}$ to translocation into the edible pods. For tomato, there was a strong physiological barrier to both $\mathrm{Pb}$ and As transfer into the fruit, as the measured fruit concentrations of $\mathrm{Pb}$ and $\mathrm{As}$ were well below the recommended limits even for the most severely contaminated soil.

Generally, the vegetable fruits (bean, tomato) were less susceptible to contamination than lettuce or carrots, although
As exceeded the recommended limits for all vegetables except tomato fruits when soil As exceeded $100-150 \mathrm{mg} \mathrm{kg}^{-1}$.

\section{Conclusion}

The extent of $\mathrm{Pb}$ and As transfer into the edible part of vegetables grown on orchard soils historically contaminated by $\mathrm{Pb}$ arsenate pesticides depended primarily on soil total $\mathrm{Pb}$ and $\mathrm{As}$ concentrations, soil $\mathrm{pH}$, and type of vegetable. Generally, As concentrations were highest in lettuce and green beans, lower in unpeeled carrots, and much lower in tomato fruit. Peeling reduced As concentrations in the carrot roots but slightly increased $\mathrm{Pb}$ in the roots. Transfer of $\mathrm{Pb}$ into vegetables was generally lower than that of As for lettuce and beans. $\mathrm{Pb}$ tended to be strongly excluded from the fruit of tomato, although not as strongly as As. Only in the most contaminated soil, containing $915 \mathrm{mg} \mathrm{kg}^{-1}$ of Pb, did any vegetable's $\mathrm{Pb}$ contamination levels exceed international standards. This exceedance occurred for carrots. However, for As, concentrations in lettuce, unpeeled carrots, and green beans exceeded the standard of $0.1 \mathrm{mg} \mathrm{kg}^{-1}$ (f.w.) at the highest soil As concentration $\left(211 \mathrm{mg} \mathrm{kg}^{-1}\right)$.

Vegetable contamination generally (with the exception of tomato) increased nonlinearly in response to soil contamination level; that is, plant uptake coefficients (UCs) increased at higher soil total $\mathrm{Pb}$ and As. In addition, lowered soil $\mathrm{pH}$ had a dramatic effect in increasing $\mathrm{Pb}$ in lettuce and carrots, in particular, but had little effect on crop As contamination.

Caution is advised in generalizing these results for commonly grown vegetables to all vegetable types; for As in particular, there is evidence for strong differences among plant species in potential for uptake. Additionally, the risk for vegetable contamination by $\mathrm{Pb}$ may be lower in the greenhouse than in the field. Research has indicated aerial deposition of dust or soil splash to be responsible for most of the contamination of field-grown leafy vegetables, and $\mathrm{Pb}$ can thereby reach substantially higher concentrations than those measured in this study [10].

\section{Acknowledgments}

This research was funded in part by the National Institutes of Health and the National Institute of Environmental Health Sciences Grant no. 15R21ES017921. The author thanks Leigh Kalbacker and Sarah Wharton for their assistance with this study.

\section{References}

[1] P. L. M. Veneman, J. R. Murray, and J. H. Baker, "Spatial distribution of pesticide residues in a former apple orchard," Journal of Environmental Quality, vol. 12, no. 1, pp. 101-104, 1983.

[2] E. Hood, "The apple bites back: claiming old orchards for residential development," Environmental Health Perspectives, vol. 114, pp. A471-A476, 2006.

[3] T. Schooley, M. J. Weaver, D. Mullins, and M. Eick, “The history of lead arsenate use in apple production: comparison of its impact in Virginia with other States," Journal of Pesticide Safety Education, vol. 10, pp. 22-53, 2008. 
[4] D. J. Kenyon, D. C. Elfving, I. S. Pakkala, C. A. Bache, and D. J. Lisk, "Residues of lead and arsenic in crops cultured on old orchard soils," Bulletin of Environmental Contamination and Toxicology, vol. 22, no. 1, pp. 221-223, 1979.

[5] K. S. MacLean and W. M. Langille, "Arsenic in orchard and potato soils and plant tissue," Plant and Soil, vol. 61, no. 3, pp. 413-418, 1981.

[6] C. F. Aten, J. B. Bourke, J. H. Martini, and J. C. Walton, "Arsenic and lead in an orchard environment," Bulletin of Environmental Contamination and Toxicology, vol. 24, no. 1, pp. 108-115, 1980.

[7] T. L. Creger and F. J. Peryea, "Lead and arsenic in two apricot cultivars and in "Gala" apples grown on lead arsenatecontaminated soils," HortScience, vol. 27, pp. 1277-1278, 1992.

[8] R. F. Bishop and D. Chisholm, "Arsenic accumulation in Annapolis valley orchard soils," Canadian Journal of Soil Science, vol. 42, pp. 77-80, 1962.

[9] R. G. Ross and A. D. Crowe, "Further studies on replant disease of apple in Nova Scotia," Canadian Plant Disease Survey, vol. 56, pp. 88-92, 1976.

[10] M. B. McBride, T. Simon, G. Tam, and S. Wharton, "Lead and arsenic uptake by leafy vegetables grown on contaminated soils: effects of mineral and organic amendments," Water, Air, and Soil Pollution, vol. 224, pp. 1378-1387, 2012.

[11] L. E. Allison, "Organic carbon," in Methods of Soil Analysis: Part 2, C. A. Black, Ed., pp. 1367-1378, American Society of Agronomy, Madison, Wis, USA, 1965.

[12] D. S. Ross and Q. Ketterings, "Recommended methods for determining soil cation exchange capacity," in Recommended Soil Testing Procedures for the Northeastern United States, Northeastern Regional Publication no. 493, pp. 75-85, 2011.

[13] M. Fleming, Y. Tai, P. Zhuang, and M. B. McBride, "Extractability and bioavailability of $\mathrm{Pb}$ and $\mathrm{As}$ in historically contaminated orchard soil: effects of compost amendments," Environmental Pollution, vol. 177, pp. 90-97, 2013.

[14] M. L. Pierce and C. B. Moore, "Adsorption of arsenite and arsenate on amorphous iron hydroxide," Water Research, vol. 16, no. 7, pp. 1247-1253, 1982.

[15] K. de Brouwere, E. Smolders, and R. Merckx, "Soil properties affecting solid-liquid distribution of As(V) in soils," European Journal of Soil Science, vol. 55, no. 1, pp. 165-173, 2004.

[16] W. Jiang, S. Zhang, X. Shan, M. Feng, Y. G. Zhu, and R. G. McLaren, "Adsorption of arsenate on soils-part 2: modeling the relationship between adsorption capacity and soil physiochemical properties using 16 Chinese soils," Environmental Pollution, vol. 138, no. 2, pp. 285-289, 2005.

[17] S. M. I. Huq, J. C. Joardar, S. Parvin, R. Correll, and R. Naidu, "Arsenic contamination in food-chain: transfer of arsenic into food materials through groundwater irrigation," Journal of Health, Population and Nutrition, vol. 24, no. 3, pp. 305-316, 2006.

[18] E. E. Codling, R. L. Chaney, and C. E. Green, "Lead and arsenic uptake by carrots grown on five orchard soils with history of lead arsenate used," in Proceedings of the ASA International Meeting Abstracts, p. 241, 2007.

[19] L. Samsøe-Petersen, E. H. Larsen, P. B. Larsen, and P. Bruun, "Uptake of trace elements and PAHs by fruit and vegetables from contaminated soils," Environmental Science and Technology, vol. 36, no. 14, pp. 3057-3063, 2002.

[20] P. D. Alexander, B. J. Alloway, and A. M. Dourado, "Genotypic variations in the accumulation of $\mathrm{Cd}, \mathrm{Cu}, \mathrm{Pb}$ and $\mathrm{Zn}$ exhibited by six commonly grown vegetables," Environmental Pollution, vol. 144, no. 3, pp. 736-745, 2006.
[21] J. R. Preer, H. S. Sekhon, B. R. Stephens, and M. S. Collins, "Factors affecting heavy metal concentration of garden vegetables," Environmental Pollution B, vol. 1, no. 2, pp. 95-104, 1980.

[22] A. M. Moir and I. Thornton, "Lead and cadmium in urban allotment and garden soils and vegetables in the United Kingdom," Environmental Geochemistry and Health, vol. 11, no. 3-4, pp. 113119, 1989.

[23] A. Raab, P. N. Williams, A. Meharg, and J. Feldmann, "Uptake and translocation of inorganic and methylated arsenic species by plants," Environmental Chemistry, vol. 4, no. 3, pp. 197-203, 2007.

[24] N. Singh and L. Q. Ma, "Assessing plants for phytoremediation of arsenic-contaminated soils," in Methods in Biotechnology, Phytoremediation: Methods and Reviews, N. Willey, Ed., vol. 23, pp. 319-347, Humana Press, Totowa, NJ, USA, 2007.

[25] S. Goldberg, S. M. Lesch, D. L. Suarez, and N. T. Basta, "Predicting arsenate adsorption by soils using soil chemical parameters in the constant capacitance model," Soil Science Society of America Journal, vol. 69, no. 5, pp. 1389-1398, 2005. 

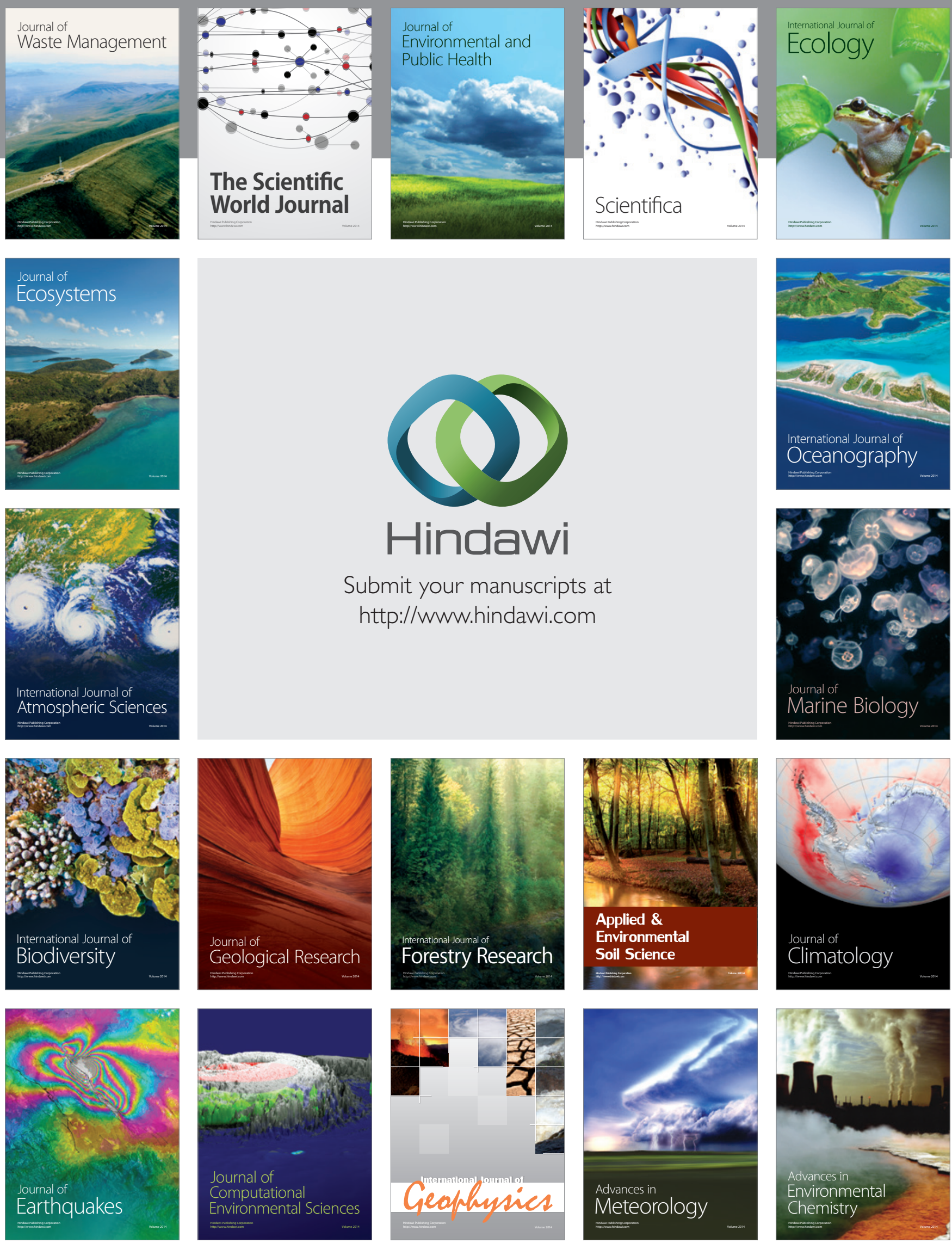